The Impact of Unemployment and Human Development Index on Poverty in Gorontalo Province 20082017
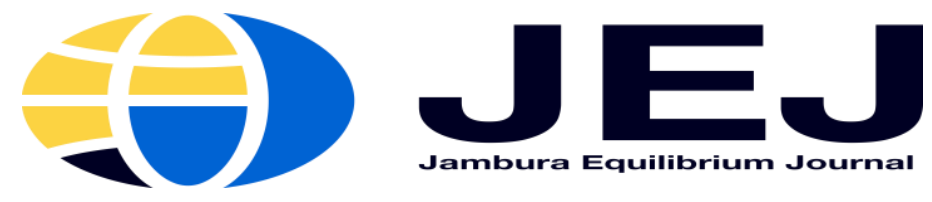

Volume 2. Issue 1. January 2020

P-ISSN 2655-9110

E-ISSN 2656-0445

http://ejurnal.ung.ac.id/index.php/equij

\title{
The Impact of Unemployment and Human Development Index on Poverty in Gorontalo Province 2008-2017
}

Lian A. Yusuf ${ }^{1}$, Sri Indriyani Dai ${ }^{2}$

Faculty of Economics, Gorontalo State University ${ }^{1,2}$

\begin{abstract}
This research aims to analyze the impact of unemployment rate and human development index on poverty in Regecies and City in Gorontalo Province. This research uses Panel Data Regression analysis with fixed effect model (FEM). This research uses regional datasets from the Registration Management Information System (SIMREG) and datasets from Central Statistics Bureau (BPS) during 2008-2017. Main findings of this research indicates that (i) unemployment rate has positive but insignificant impact on poverty rate; (ii) human development index has positive and significant impact on poverty rate.
\end{abstract}

Keywords: Unemployment Rate; Human Development Index (HDI); Poverty.

Poverty may impose a problem in economic development. Poverty itself is associated with many aspects in life, such as income, health, education, and so on. Poverty is also known as the inability of a person to satisfy minimum standard of living. This minimum standard of living is mainly based on the state of health, moral living, and self-esteem of those classified as the poor.

As explained before, poverty may impose as a problem in economic development. Poverty may become a benchmark that needs to be reduced for developing countries in order to redistribute the economic growth to all population.
Therefore, poverty alleviation strategies is really important for developing countries.

Overcoming poverty is essential in developing countries. Poverty reduction policies need to focus on the empowerment of the poor to be independent, in economic, socio-cultural, and political aspects. Hence, poverty alleviation strategies need to satisfy all aspects that is associated with poverty itself. Therefore, this research will further investigate the factors that is associated with poverty to create poverty alleviation strategies.

This research would specifically analyse the issue of poverty in Gorontalo Province, because poverty rate in Gorontalo 
The Impact of Unemployment and Human Development Index on Poverty in Gorontalo Province 20082017

is relatively high compared to other provinces in Indonesia. According to BPS (2017), poverty is included as one of the fundamental problems in economic development in Gorontalo Province.

In addition, poverty rate in is also accompanied with stagnant unemployment rate as it is evident in Table 1 and Table 2. This phenomenon needs to be investigated to further understand the association between each variables.

Gorontalo Province is relatively high and it

Table 1. Number of Poor People in Gorontalo Province 2017

\begin{tabular}{|l|l|c|c|}
\hline No. & \multicolumn{1}{|c|}{ Regencies/City } & Total Population & Poor (\%) \\
\hline 1. & Boalemo & 158.333 & 21.85 \\
\hline 2. & Gorontalo & 374.923 & 20.55 \\
\hline 3. & Pohuwato & 153.991 & 21.27 \\
\hline 4. & Bone Bolango & 157.186 & 17.81 \\
\hline 5. & Gorontalo Utara & 112.975 & 19.23 \\
\hline 6. & Gorontalo, City & 206.454 & 5.70 \\
\hline
\end{tabular}

Source: BPS, 2018

Table 2. Unemployment Rate and Labour Force Participation Rate 2008-2017

\begin{tabular}{|c|c|c|}
\hline Year & Unemployment Rate (percent) & $\begin{array}{c}\text { Labour Force Participation Rate } \\
\text { (Percent) }\end{array}$ \\
\hline 2008 & 5.65 & 62.40 \\
\hline 2009 & 5.89 & 63.77 \\
\hline 2010 & 5.16 & 64.42 \\
\hline 2011 & 6.68 & 64.03 \\
\hline 2012 & 4.44 & 62.59 \\
\hline 2013 & 4.15 & 61.46 \\
\hline 2014 & 4.18 & 62.84 \\
\hline 2015 & 4.65 & 63.65 \\
\hline 2016 & 2.76 & 67.89 \\
\hline 2017 & 4.28 & 64.78 \\
\hline
\end{tabular}

Furthermore, we need to estimate human development index as it has indirect impact on the complexity of poverty. The Human Development Index (HDI) is a breakthrough in assessing human development. Previous studies mainly found that there is negative association between HDI and poverty, where ideally, if HDI is relatively high, means that the individual quality of life is high, that it is 
The Impact of Unemployment and Human Development Index on Poverty in Gorontalo Province 20082017

supposed to be followed with low level of poverty. However, the HDI of Gorontalo province is relatively low compared to other provinces in Sulawesi as it is evident in Figure 1.

Figure 1. Human Development Index in Sulawesi 2017

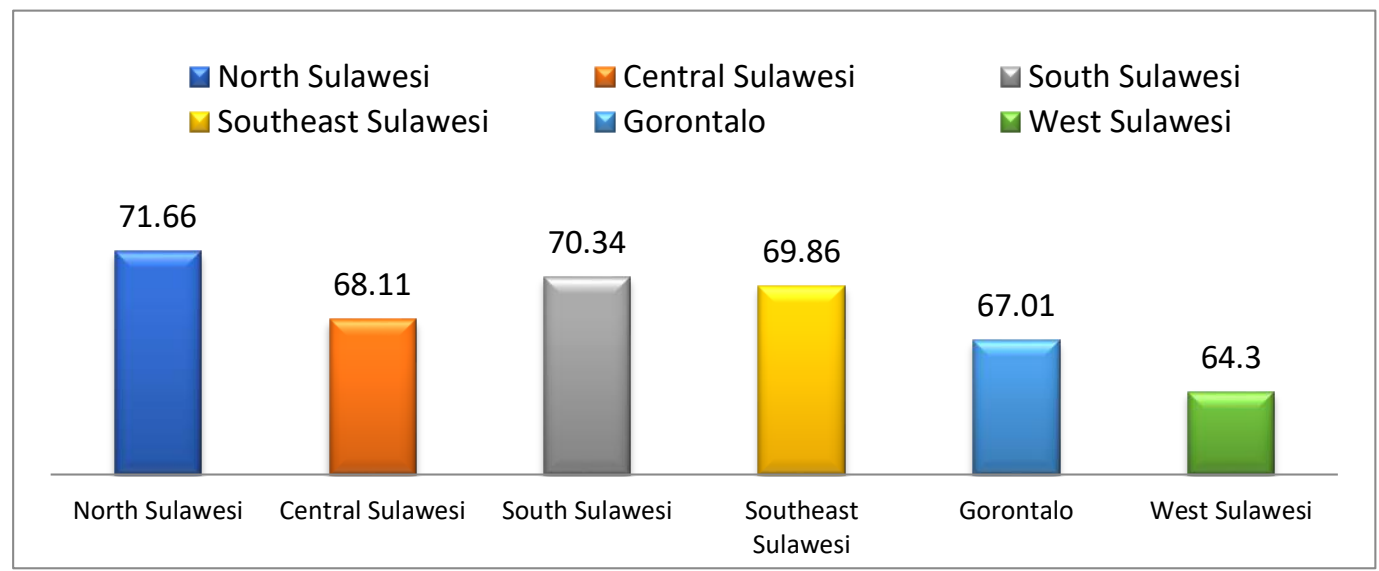

Source: BPS, 2018

According to the explanation above, this research would further investigate the impact of unemployment rate and human development index on poverty in Gorontalo Province.

\section{LITERATURE REVIEW}

Poverty is a complex problem regarding economic development. Poverty may have been associated with noneconomic dimensions, but it is mainly referred to the economic dimension.

Subandi (2012) stated that poverty alleviation strategies need to address the quality of human resources due to poverty trap. Huraerah (2012) also stated that poverty alleviation strategies need to prioritize structural, cultural, and political aspects into consideration.

Unemployment also has indirect impact on poverty, because unemployed people mostly classified as the poor due to their inabilities in fulfilling basic needs. While on the other hand, human development index also portrays individual ability, but through more systematic aspects such as income level, health, and education level. Both factors may have direct and indirect impact on poverty due to the complexity of poverty itself.

Previous studies found different sets of results regarding the association between 
unemployment, human development index, and poverty. Meriyanti (2015) further validates that human development index has significant impact on poverty alleviation strategies, while Satriani (2014) found that unemployment and human development index has insignificant impact on reducing poverty rate.

Based on previous studies, this research hypothesizes that there is association between unemployment, human development index, and poverty. Through the conceptual framework, unemployment is hypothesized to have negative impact on poverty, while higher human development index may lead to lower poverty rate.

\section{RESEARCH METHODOLOGY}

This research uses secondary datasets from BPS and Registration Management Information System (SIMREG) BAPPENAS and other resources. This research uses datasets of unemployment rate, human development index, and poverty rate of five regencies and one city in Gorontalo Province during 2008-2017.

This research uses panel data regression in estimating the impact of unemployment and human development index on poverty in Gorontalo Province. The panel data regression model is written in Equation 1 as follows:

$$
\begin{gathered}
\text { Poverty }_{i, t}=\alpha_{0}+\alpha_{1} \text { UNEMP }_{i, t}+ \\
\alpha_{2} H D I_{i, t}+\varepsilon_{i, t}
\end{gathered}
$$

where Poverty i,t is poverty rate of regencies $i$ during period $t ; U N E M P_{i, t}$ is unemployment rate of regencies $i$ during period $t ; H D I_{i, t}$ is human development index of regencies $i$ during period $t$.

\section{RESULTS AND DISCUSSION}

\section{Model Specification Test}

This research applies Chow Test to determine the model specification. Chow Test will specifically decide whether Common Effect Model or Fixed Effect Model needs to addressed in this research The decision in rejecting or not rejecting the depend on the value of chi-square. If the value of chi square $\left(\mathrm{X}^{2}\right)>$ value of table chisquare $\left(\mathrm{X}^{2}\right)$, then $\mathrm{H}_{0}$ is rejected and the model used in this research is the fixed effect model. If the value of chi square $\left(\mathrm{X}^{2}\right)$ $<$ value of table chi-square $\left(\mathrm{X}^{2}\right)$, then $\mathrm{H}_{\mathrm{o}}$ is not rejected and the model used is random effect.

Results of Redundant Fixed Effect Test-Likelihood Ratio (Chow Test) in this research are as follows: 
The Impact of Unemployment and Human Development Index on Poverty in Gorontalo Province 20082017

Table 3. Redundant Fixed Effect Test-Likelihood Ratio (Chow Test)

\begin{tabular}{llll}
\hline $\begin{array}{l}\text { Redundant Fixed Effects Tests } \\
\text { Test cross-section fixed effects }\end{array}$ & & \\
\hline \hline Effects Test & Statistic & d.f. & Prob. \\
\hline \hline Cross-section F & 129.03059 & $(5,52)$ & 0.0000 \\
Cross-section Chi-square & 155.745667 & 5 & 0.0000 \\
\hline \hline
\end{tabular}

Source: Author's Calculation, 2019

From the results of the Chow Test above shows that the value of chi-squares $\left.\left(\mathrm{X}^{2}\right),\right)>$ chi-squares $\left.\left(\mathrm{X}^{2}\right),\right)$ with a probability value $(\mathrm{p}$-value $)=0.0000$ which is lower than the significance level $(\propto=$ 0.05), then the most appropriate model for this research is the Fixed Effect Model (FEM).

\section{Selection of FEM and REM with Hausman Test}

As estimated through Chow Test, it is found that the most appropriate model in this research is FEM. Consequently, we need to determine whether FEM or REM is the most appropriate model used in this research. The specification is developed with Hausman Specification Test. If Hausman test results show that the criteria of the Chi-Square statistics < table ChiSquare, then the appropriate model is REM. Conversely, when the value of Hausman statistics shows that Chi-Square statistics > Chi-Square Tables, then the most appropriate model is FEM.

Hausman test results are as follows:

Table 4. Hausman Specification Test

\begin{tabular}{llll}
\hline $\begin{array}{l}\text { Correlated Random Effects - Hausman Test } \\
\text { Test cross-section random effects }\end{array}$ & \\
\hline \hline & Chi-Sq. Statistic Chi-Sq. d.f. & Prob. \\
Test Summary & 11.035569 & 2 & 0.0040 \\
\hline \hline Cross-section random & & \\
\hline
\end{tabular}


From the results of the Hausman Test above shows that the value of chisquares $\left(X^{2}\right)>$ table chi-squares $\left(X^{2}\right)$ significant at 5\%, therefore the most appropriate model in this research is FEM.

\section{Multicollinearity Testing}

Multicollinearity is one of the classical assumptions that needs to be satisfied in BLUE. Multicollinearity referred to the absence of linear relationship between independent variables. To detect the multicollinearity, we measure the Variance Inflation Factor (VIF) of each RSquare $\left(R^{2}\right)$.

Table 5. Multicollinearity Test Results

\begin{tabular}{|lcc|}
\hline Variable & R-Square & VIF \\
\hline Economic Growth & 0.497727 & 1.090 \\
\hline Unemployment Rate & 0.655567 & 2.902 \\
\hline
\end{tabular}

The results above show that the value of VIF of the two independent variables is less than ten $(<10)$, thus, it is safe to say that there is multicollinearity between the independent variables in the model.

\section{Autocorrelation Testing}

Autocorrelation means that there is no correlation between one each observation regarding the time frame of the analysis. To detect autocorrelation, we need to measure Durbin-Watson (DW) method. DW Method is satisfied under following criteria:

- If the value: $1.65<\mathrm{DW}<2.35$, it can be concluded that autocorrelation did not occur.
- If the value: $1.21<\mathrm{DW}<1.65$ or $2.35<\mathrm{DW}<2.79$, no conclusion can be drawn.

- If the value: DW <1.21 or DW> 2.79 , it can be concluded that autocorrelation occurred

From the results of the above analysis, the Durbin Watson value is 1.175966 . This value is less than 1.21 , so there is autocorrelation in the model. However, with the consideration that the regression model obtained in this study is not used for forecasting / forecasting, the impact of this autocorrelation can be ignored in this research. 
The Impact of Unemployment and Human Development Index on Poverty in Gorontalo Province 20082017

\section{Panel Data Regression}

According to previous analysis, this research uses FEM to estimate the impact of unemployment rate and human development index on poverty in Gorontalo Provinces. Empirical results estimated with FEM is evident in Table 6.

Table 6. Estimated Panel Data Model of Poverty in Gorontalo Province Dependent Variable: POVERTY?

\begin{tabular}{lcccr}
\hline \hline \multicolumn{1}{c}{ Variable } & Coefficient & Std. Error & t-Statistic & Prob. \\
\hline \hline C & 10.64311 & 4.028196 & 2.642154 & 0.0109 \\
UNEMP? & 0.087998 & 0.120955 & 0.727527 & 0.4702 \\
HDI? & 0.100079 & 0.059418 & 1.684319 & $0.0981^{*}$ \\
\hline \hline R-squared & 0.954619 & & & \\
Adjusted R-squared & 0.948509 & & 1.175966 \\
F-statistic & 156.2631 & Durbin-Watson stat & \\
Prob(F-statistic) & 0.000000 & & & \\
\hline \hline
\end{tabular}

Source : Author's Calculation, 2019

Based on the empirical results, the model of this research is as follows:

$$
\begin{gathered}
\text { Poverty }_{i, t}=10.643+ \\
0.087 \text { UNEMP }_{i, t}+0.100 H D I_{i, t}+\varepsilon_{i, t}
\end{gathered}
$$

This empirical result shows that if other factor were ignored, average poverty rate in Gorontalo Province would reach 10.64 percent. Moreover, unemployment rate has positive and significant impact on poverty rate, where one percent of increase in unemployment rate would raise poverty rate by 0.087 percent. While human development index also has positive and significant impact, where one percent increase of human development index, would increase poverty rate by 0.100 percent.

\section{Results of Fixed Effect Model}

Results of FEM panel data regression is evident in Table 7. From 5 regencies and 1 city in Gorontalo Province, it can be seen through the FEM analysis that Boalemo Regencies has slightly higher coefficient compared to other regencies. Then the district that was corrected quite positively to poverty was Gorontalo District which had a coefficient value of 3.744 , Pohuwato District was positively corrected with a coefficient value of 2.95 percent, after that only Gorontalo City which had a fixed effect coefficient value was Gorontalo 
The Impact of Unemployment and Human Development Index on Poverty in Gorontalo Province 20082017

City which was positively corrected 2.19 percent poverty level. Bone Bolango Regency the percentage of poverty is corrected positively with a coefficient value of 0.216 percent, and finally a district that has a poverty reduction reflected by a regression coefficient of -12.96 percent, meaning that poverty in Gorontalo District shows a declining trend.

Table 7. Estimaeted FEM Panel Data Regression on Poverty in Gorontalo Provinces Dependent Variable: POVERTY?

\begin{tabular}{ccccc}
\hline \hline Variable & Coefficient & Std. Error & t-Statistic & Prob. \\
\hline \hline C & 10.64311 & 4.028196 & 2.642154 & 0.0109 \\
UNEMP? & 0.087998 & 0.120955 & 0.727527 & 0.4702 \\
HDI? & 0.100079 & 0.059418 & 1.684319 & 0.0981 \\
Fixed Effects (Cross) & & & & \\
_BOALEMO_C & 3.858905 & & & \\
_BONEBOLANGO-C & 0.216166 & & & \\
_POHUWATO_C & 2.950447 & & & \\
_KABGORONTALO--C & 3.744584 & & & \\
_KOTAGORONTALO--C & 2.199115 & & & \\
_GORONTALOUTARA--C & -12.96922 & & & \\
\hline \hline
\end{tabular}

Source : Author's Calculation, 2019

\section{CONCLUSION}

This study aims to investigate the impact of unemployment rate and human development index on poverty in Gorontalo Province. Based on the above explanation, it can be concluded that unemployment rate has positive but insignificant impact on poverty in Gorontalo Province. While human development index (HDI) has positive and significant impact on poverty rate in Gorontalo Province.
Based on the conclusion, this research further recommends that each government need to provide training or workshops to further alleviate poverty, government also need to evaluate policies regarding education, health, and economic dimensions to tackle poverty. Moreover, this research also suggests that government need to integrate or coordinate poverty alleviation strategies on the national or local level. 


\section{REFERENCES}

Alhudori M. 2017. Pengaruh IPM, PDRB, dan Jumlah Pengangguran Terhadap Penduduk Miskin di Provinsi Jambi. Jurnal. Volume. 1. No. 1.

Anggraheni Y. 2016. Pengaruh Pertumbuhan Ekonomi, Pengangguran, dan Kemiskinan Terhadap Indeks Pembangunan Manusia di Kabupaten/Kota di Jawa Tengah 2010-2013. Skripsi. Fakultas Ekonomi dan Bisnis Islam Universitas Islam Negeri Sunan Kalijaga.

Adi N. P. 2015. Pengaruh PDRB, Tingkat Pendidikan, dan Pengangguran Terhadap Kemiskinan di Kota Yogyakarta Tahun 1999-2013. Skripsi. Fakultas Ekonomi. Universitas Negeri Yogyakarta.

Arham, Muhammad. 2014. Kinerja Perekonomian dan Keuangan Daerah. Edisi.1, Penerbit. Depublish.

BPS (Jumlah Penduduk dan Penduduk Miskin tahun 2012-2017)

BPS (Tingkat Pengangguran Terbuka dan Tingkat Partisipasi Angkatan Kerja tahun 2012-2107)

BPS (Indeks Pembangunan Manusia tahun 2012-2017)

Fatima, S. N. 2018. Analisis Pengaruh Kemiskinan, Pengangguran, Pertumbuhan Ekonomi, Terhadap Indeks Pembangunan Manusia di Provinsi Banten Tahun 2010-2015. Skripsi.
Universitas Islam Indonesia Fakultas Ekonomi Yogyakarta.

Irhamni. 2017. Pengaruh Jumlah penduduk, Pengangguran, dan Pengeluaran Pemerintah Terhadap Kemiskinan di Indonesia Tahun 1986-2015. Skripsi. Progam Studi Ekonomi Fakultas Ekonomi. Universitas Negeri Yogyakarta.

Khoirunnisa. R. Dhiya. 2018. Pengaruh Kinerja Keuangan Daerah terhadap Indeks Pembangunan Manusia dengan Belanja Modal sebagai Variabel Intervening. Universitas Lampung.

Kaharu, U. 2004. Ekonomi Pembangunan Antara Gagasan, Teori dan Aplikasinya. Edisi Pertama. Nurul Jannah: Gorontalo.

Latumerissa R. J. 2015. Perekonomian Indonesia dan Dinamika Ekonomi Global. Edisi Asli, Jakarta: Penerbit. Mitra Wacana Media.

Meriyanti K. N. 2015. Pengaruh Program Indeks Pembangunan Manusia (IPM), Terhadap Pengentasan Kemiskinan di Kecamatan Buleleng Tahun 2011-2014. Jurnal. Volume: 5. No.1. Hal 1-10.

Mopangga H. 2014. Ilmu Ekonomi: Pengantar Analitis \& Praktis.Halaman 316.

Novriansyah A. M. 2018. Pengaruh Pengangguran dan Kemiskinan Terhadap Pertumbuhan Ekonomi 
di Provinsi Gorontalo. Jurnal. Volume. 1. No.1. Hal. 59-71.

Paramita A. D. Ida B. P. P. 2015. Pengaruh Investasi dan Pengangguran Terhadap Pertumbuhan Ekonomi Serta Kemiskinan di Provinsi Bali. EJurnal Ep Unud, 4 [10] : 11941218 .

Saputra W. A. 2011. Analisis Pengaruh Jumlah Penduduk, Pdrb, Ipm, Pengangguran Terhadap Tingkat Kemiskinan. Di Kabupaten/Kota/Jawa Tengah. Skripsi. Fakultas Ekonomi. Universitas Diponegoro. Semarang.

Wijayanto R. D. 2010. Analisis Pengaruh Pdrb, Pendidikan, dan Pengangguran Terhadap Kemiskinan di Kabupaten/Kota Jawa Tengah Tahun 2005-2008. Skripsi. Fakultas Ekonomi. Universitas Diponegoro. Semarang.

Yacoub, Y. 2012. Pengaruh Tingkat Pengangguran Terhadap Tingkat Kemiskinan Kabupaten/Kota di Provinsi Kalimantan Barat. Jurnal Volume 8. Nomor 3, Oktober 2012, Hal.176-185,
ISSN 1693-9093. Jurusan Ilmu Ekonomi Fakultas Ekonomi Universitas Tanjungpura Pontianak.

Zurisdah, Z. 2016. Pengaruh Tingkat Pengangguran Terbuka, Terhadap Tingkat Kemiskinan di Provinsi Banten. Skripsi. Fakultas Ekonomi dan Bisnis Islam Institut Agama Islam Negeri (IAIN) Sultan Maulana Hasanudin Banten. 